\title{
Comment
}

\section{Authoritarian Global Governance? The Russian-Chinese Joint Statement of March $2021^{*}$}

I. Content and Function of the Joint Statement 293

II. Human Rights (para. 1) 295

$\begin{array}{lr}\text { III. Democracy (para. 2) } & 295\end{array}$

IV. The Two-tier Concert of Global Powers (para. 3) 297

V. Other International Law Issues (para. 3) 299

VI. On Multilateral Cooperation (para. 4) 300

$\begin{array}{lr}\text { VII. Prospects } & 301\end{array}$

\section{Content and Function of the Joint Statement}

On 23 March 2021, China and Russia, emboldened by China's apparent success in the fight against SARS-CoV-2, adopted a Joint Statement on 'Certain Aspects of Global Governance in Modern Conditions', where they put forward their vision for the post-pandemic world. ${ }^{1}$ This is an extraordinary document that did not receive the attention it deserves. In the Statement, the two countries developed their grand political project for an authoritarian global governance in the current era.

The document has many ambiguities, raises questions that it does not answer, and its terms oscillate between the legal and the political. As it was signed at the time, when academic discussion has started exploring the potentialities of what was called 'authoritarian international law', it is important to view it through this perspective and try to reconstruct its fundamental concepts and principles, because it constitutes an important step towards the deepening of the East/West differentiation on international legal policy. The Joint Statement incorporates also the Declaration of the two countries of 25 June 2016 'on the Promotion of International

* I thank Armin von Bogdandy, Anne Peters, Matthias Hartwig, and Carolyn Moser for their constructive critique and insights. Responsibility remains exclusively with the author.

1 Joint Statement by the Foreign Ministers of China and Russia on Certain Aspects of Global Governance in Modern Conditions, no. 539-23-3-2021.

2 Tom Ginsburg, 'Authoritarian International Law?', AJIL 114 (2020), 221-260. 
Law'3 by reference and therefore the two documents, the recent one on global governance and the older one on international law, should be read together, where appropriate. ${ }^{4}$

The idea of governance has always been difficult to define, because of its complexity, but there are some generally accepted features of it. Briefly, governance is distinguished from government by elements of informality, whilst 'global governance' indicates the existence of networks of State and non-State actors with strong heterarchical elements. International organisations, international public authority and international public law, ${ }^{5}$ are components of the overall system of global governance. Governance is considered as a core feature of the process of globalisation and of an over-complex and functionally differentiated world society with plural centres of power and authority. ${ }^{6}$

The Russian-Chinese notion of global governance is based on a different understanding. The two states detect a fundamental change in the balance of power as consequence of the pandemic, which allegedly justifies their vision for the post-pandemic world. The Joint Statement emphasises in its preambular paragraph that the pandemic 'has served as a catalyst for change in the world order and provoked even greater imbalances in the global governance system', and that 'the world has entered a period of high turbulence and rapid change'. The two powers call upon the international community to cooperate 'in the interests of global security and geopolitical stability' and 'to contribute to the establishment of a fairer, more democratic and rational multipolar world order'.

The Joint Statement considers that the time has come for a different system of global governance, managed by a two-tier Concert of Global Powers through technocratic decision-making, where the significance of democracy, human rights, and international organisations would be marginalised. As the Statement uses coded language, attempting to present the radical departure from the current international system as continuity, it is appropriate to interpret its concepts and principles and test their coherence. In reality, the existing elements of continuity are integrated in an agenda focusing on a sweeping overhaul of the current system.

3 Declaration of 25 June 2016, S/2016/600, 12 July 2016. Going further back, there is also a 'Joint Declaration on a Multipolar World and the Establishment of a New International Order' from 23 April 1997, S/1997/384, 20 May 1997, adopted by then Presidents Boris Yeltsin and Jiang Zemin, under completely different geopolitical circumstances.

4 Para. 3 of the Joint Statement (n. 1).

5 On this term, see Armin von Bogdandy, Matthias Goldmann and Ingo Venzke, 'From Public International to International Public Law: Translating World Public Opinion into International Public Authority', EJIL 28 (2017), 115-145.

6 See generally Karl-Heinz Ladeur, 'Governance, Theory of', (last updated September 2010), in: Anne Peters and Rüdiger Wolfrum (eds), MPEPIL (online edn, Oxford: Oxford University Press 2010); <www.mpepil.com> last access 7 June 2021. 


\section{Human Rights (para. 1)}

First, the Joint Statement recognises the universality, indivisibility, and interdependence of all human rights, but avoids a straightforward commitment to respect and safeguard them and fails to acknowledge their inviolability. The signatories claim that sustainable development 'contributes to respect for all human rights' by raising the standards of living, and that 'all states should protect and implement human rights in the political and socioeconomic spheres'. And then comes the real issue: 'It is time to stop attaching a political agenda to the topic of human rights' and using them as pretext for interference.

Obviously, it could not be expected from the Joint Statement to endorse liberal rights, but it could be expected from Russia and China to present an alternative rights perspective. Russia as a value conservative power ${ }^{7}$ and China through its Confucian culture ${ }^{8}$ could have offered a critique of liberalism and present their own interpretive alternative on human rights. The Statement does not present any concept of rights at all and this may indicate the existence of differences between the two powers. Russia, for instance, is a member of the Council of Europe and contracting party to the European Convention on Human Rights, a fact that makes a normative consensus with China more difficult to frame. However, the two countries agree on the centrality of 'sustainable development' as a means to achieve respect of the human rights system as a whole. Nevertheless, this path for the realisation of rights looks unreal, because as China prospers, the more oppressive it becomes. Human rights have no content in the Statement, and the two powers show support for something that they are unwilling or unable to specify. Their real concern is the alleged foreign interference as consequence of the potential human rights violations they commit.

\section{Democracy (para. 2)}

Second, the Statement recognises that 'democracy is one of the achievements of humanity', but makes no mentioning of the rule of law, checks and

7 Glenn Diesen, 'Russia as an International Conservative Power: the Rise of the Right-wing Populists and Their Affinity towards Russia', Journal of Contemporary European Studies 28 (2020), 182-196.

8 See indicatively Robert Ames and Peter Hershock (eds), Confucianisms for a Changing World Cultural Order (Honolulu: University of Hawaii Press 2017), in particular: Lee SeungHwan, 'Confucianism as an Antidote for Liberal Self-Centeredness - A Dialogue between Confucianism and Liberalism' in: Ames and Hershock (eds) (n. 8), 29-42. 
balances, periodic and fair elections, or a multiparty political system. The Statement reduces democracy to the minimal aspect of 'the legislatively stipulated people's rule', in which everyone is entitled 'to participate in governing their own country, while using the power granted to them for legitimate purposes' (obviously for purposes prescribed by an authoritarian constitution). It further emphasises that every independent State has the right to determine its own path to development, and that there is no 'single standard' for democracy.

Even though there is indeed no single model of democracy in international law, and despite the uncertainties associated with a right to democratic governance or a customary principle of democracy in the East/West and North/South contexts, there is significant United Nations (UN) and state practice on the organisation of free elections. Moreover, there are relevant human rights of procedural or substantive order enabling democratic governance, such as the freedom of opinion, expression and association, the freedom of information, the right of universal and equal suffrage, and the right of political participation, as recognised by Art. 25 International Covenant on Civil and Political Rights on the right to participation in public affairs and the right to vote and interpreted by General Comment No. 25. ${ }^{9}$ Here, there is a disjunction between the two powers, as Russia has ratified the Covenant, but China has signed, but not ratified. ${ }^{10}$

The Joint Statement understands democracy as an empty shell, just as human rights, and emphasises that interference in the internal affairs of sovereign states under the pretext of "promoting democracy" is unacceptable'. The two powers do not accept any meaningful normative standards, apart from 'people's will', even avoiding the term 'democratisation' to indicate at least that an evolutionary process towards less authoritarianism could be in sight in some future time. The Soviet Union could easily fulfil the definition of a democratic system in the sense of 'legislatively stipulated people's rule' and it seems that Russia and China are advocating a return to the pre-1989 normative state of affairs.

9 Gregory H. Fox, 'Democracy, Right to, International Protection', (last updated March 2008), in: Anne Peters and Rüdiger Wolfrum (eds), MPEPIL (online edn, Oxford: Oxford University Press 2008); <www.mpepil.com> last access 7 June 2021; see also the groundbreaking article of Thomas Franck, 'The Emerging Right to Democratic Governance', AJIL 86 (1992), 46-91. See also recently Sigrid Boysen, 'Remnants of a Constitutional Moment - the Right to Democracy in International Law' in: Andreas von Arnauld, Kerstin von der Decken and Mart Susi (eds), The Cambridge Handbook of New Human Rights (Cambridge: Cambridge University Press 2019), 465-480; Samantha Besson, 'The Human Right to Democracy in International Law - Coming to Moral Terms with an Equivocal Legal Practice' in: von Arnauld, von der Decken and Susi (eds) (n. 9), 481-489.

$10<$ https://treaties.un.org/>. 


\section{The Two-tier Concert of Global Powers (para. 3)}

The most important element of the Joint Statement is the definition of the particular responsibilities of global powers and the objective of a grand arrangement among them. The two states develop here some preliminary ideas for a new Concert, dressed in the language of the UN system, but actually lying outside of it. Initially, the Statement pays lip-service to the United Nations and international law, but without offering any new ideas on how to make the Organisation more effective, or how to improve the governance of legal regimes. The two powers support the maintenance of international peace and security, which is the core function of the United Nations, but they introduce a new parallel concept:

'all states [...] should make efforts to maintain the inviolability of the international relations system in which the United Nations plays a central role'. ${ }^{11}$ In the current language of international law, 'inviolability' is used mainly in relation to borders or rights. Obviously, an international relations system cannot be 'inviolable', because a system of relations cannot be frozen, but is in constant flux and evolution. What the two powers have probably wanted to emphasise is the necessity of arrangements securing regime inviolability and the stability of their geopolitical and geo-economic spheres of interest.

The conceptual move from the maintenance of peace to the inviolability of the international relations system leads to the core idea of Joint Statement, namely the proposal for a two-tier Concert of Global Powers. Thus, the signatories 'call on the major global powers, primarily the permanent members of the UN Security Council [...] to be in the forefront of defending international law as well as the world order based on it'. And then: 'in the context of escalating global political turbulence, there is a need to hold a summit of the permanent members of the UN Security Council in order to establish a direct dialogue between them on ways to resolve common problems facing humanity, in the interest of maintaining global stability' (para. 3 of the Statement).

Prima facie, this proposal appears rather ordinary: a P5 Summit, or an enlarged informal gathering (G10?), or a political commitment of global powers to international law and world order seem almost banal. On a closer look, this is a radical proposal. First, the Joint Statement uses the broad concept of 'major global powers', and the narrower concept of the P5, included within the former. If the P5 are legally determined, ${ }^{12}$ the 'major global powers' are not. Second, the major global powers should defend (i) international law and (ii) the world order based on it. The narrower circle of

11 Emphasis added by the author.

12 Art. 23 (1) UN Charter. 
the P5 should (i) hold a summit, (ii) establish a direct dialogue, (iii) resolve common problems facing humanity, (iv) in the interest of maintaining global stability. Third, the P5 decide and the global powers implement and safeguard. And fourth, no role is provided for the UN institutions.

This is a nascent proposal for an alternative global governance system. The Statement proposes the creation of a Concert of Global Powers with a core (P5) armed with authority, and a periphery of additional global powers that will implement the policies together with the P5. Thus, the core will be capable of exercising direct influence on the other major powers. 'Major global powers' are not only great powers with planetary interests and military capacity to defend their spheres of influence, but also powers with major regional, interregional, or global influence. This may include the other members of the BRICS, such as India, Brazil, and South Africa, and powers like Indonesia, Japan, Germany, and the EU. Obviously, the Statement does not recognise equal status and diplomatic weight to all these countries, not least because China's vision for a broader coalition with the BRICS ${ }^{13}$ did not yield the expected results. This is therefore Plan B for embedding other global powers into a larger framework of partners. One of the plan's weak points is the lack of any indication on the process of selection of the other major global powers and affects the legitimacy of the idea in the eyes of the international community.

The extra-constitutional status of the P5 with regard to the United Nations and the transition from the threats and preservation of peace to the inviolability of the international relations system' and to the resolution of 'common problems facing humanity' signify a different understanding of international peace and security than that developed by the UN Security Council over decades. Furthermore, the two powers distance themselves from the Council in another more visible manner: The Joint Statement does not call for a High Level meeting of the UN Security Council, as it has already happened in the organ's past practice, ${ }^{14}$ or for an Emergency Session of the UN General Assembly. Although it would have been possible to hold private meetings of the P5 in the framework of the UN Security Council activities, the Statement does not call for an involvement of this organ and stresses the element of direct dialogue among the P5. This can only mean that the notion of the P5 in the Joint Statement is disconnected from, or very loosely linked to, its institutional setting and assumes the format of an informal global governance body, steering the action of the international community via the support of the other global powers.

13 Congyan Cai, 'New Great Powers and International Law in the 21st Century', EJIL 24 (2013), 755-795.

14 The UN Library identified at least nine such meetings since 1992, available at <https:// ask.un.org/> (last viewed on 20 May 2021). 


\section{Other International Law Issues (para. 3)}

Whilst the 2021 Joint Statement outlines the main elements of global governance, including international law, the 2016 Declaration focused specifically on international law. It is therefore necessary to comment on two points raised by the Declaration: sovereign equality and international legal policy. First, the Declaration considers sovereign equality as the core principle of international law (para. 2). According to the two Powers, sovereign equality is not only 'crucial for the stability of international relations', but is central for the interpretation and application of international law.

Second, the Declaration includes the interlinkage of the UN Charter and the Friendly Relations Declaration with the Five Principles of Peaceful Coexistence and China's formula of the 'community of shared future for mankind' (para. 1). This hybrid of principles and policies offers an idea of the intention of the two powers to steer the course of the evolution of international law to a desirable direction. The peaceful coexistence is an old concept originating from the early Bolshevik era in the USSR, it has played a role before and during the Cold War, was adopted by China and India in 1954 and, next year, by the Communique of the Bandung Conference. ${ }^{15}$ The community of shared future of mankind is a novel concept, presented in detail by China's President Xi Jinping in 2017 in the UN Office in Geneva. ${ }^{16}$ The Five Principles cannot be expected to offer new insights, but should be taken as a call for mutual toleration and avoidance of war, whilst the community of shared future is the basic legal policy formula of China, endorsed here also by Russia. This formula is one of the main pillars of norm entrepreneurship attempted by China and has been included in some UN resolutions. ${ }^{17}$

It is not clear whether the ideas presented in the 2021 Joint Statement are broadly based on the principle of the community of shared future as operationalised in the field of global governance, or whether the additional concepts of 'inviolability of the international relations system' and of the resolution of 'common problems facing humanity' are separate and incon-

15 See Carlo Panara and Paul French, 'Peaceful Coexistence', (last updated July 2019), in: Anne Peters and Rüdiger Wolfrum (eds), MPEPIL (online edn, Oxford: Oxford University Press 2019); <www.mpepil.com> last access 7 June 2021. For the Chinese perspective, see Zhipeng He and Lu Sun, A Chinese Theory of International Law (Heidelberg/Berlin: Springer 2020), 143-156.

16 Xi Jinping, 'Towards a Community of Shared Future for Mankind' in: Xi Jinping, The Governance of China (Vol. II, Beijing: Foreign Languages Press 2019), 588-601. See also Zhang Wei and Chang Jian (eds), Human Rights and the Concept of a Human Community with a Shared Future (Leiden/Boston: Brill Nijhoff 2020).

17 Congyan Cai, The Rise of China and International Law - Taking Chinese Exceptionalism Seriously (Oxford: Oxford University Press 2019), 107-108. 
gruent categories. The semantics of the two powers are occasionally opaque and difficult to interpret. It seems that the community of shared future is a more appropriate concept for UN resolutions, whilst the terms of the Joint Statement are more akin to diplomatic formulas and more appropriate for the envisaged informal system of global governance.

\section{On Multilateral Cooperation (para. 4)}

The last part of the Joint Statement is about multilateral cooperation (para. 4). The key terms here are the 'non-ideological approach' to cooperation, improvement of the efficacy of multilateral platforms, and optimisation the system of global governance. These concepts offer some access to the deeper thinking of the two powers.

The 'non-ideological approach' can have two possible meanings: (i) lack of ideological divisions or (ii) a technocratic solution to global problems. First, the phrase may be an acknowledgement that there are no fundamental ideological divisions in the contemporary world anymore. This interpretation is rather questionable, considering the nature and orientation of the Joint Statement, which demonstrates rather deep divisions between the authoritarian and the liberal approaches to governance. After all, these divisions motivated the signatories of the Joint Statement to devise the authoritarian model of governance as an alternative to liberalism.

Second, 'non-ideological' transits to 'technocratic', as the terms 'efficacy' and 'optimisation' indicate. Indeed, there is an expectation in some policy quarters that the so-called 'Asian technocracy' could promote a more efficient model of governance with authoritarian features, but allegedly larger problem-solving capacities than the West, such as practiced by Singapore and China. ${ }^{18}$ In addition, for China, effective and meritocratic leadership is the key element for success in domestic and global governance. ${ }^{19}$ Thus, the signatories advance the idea of a top-down technocratic path for global governance as a solution to the problems of humanity.

One of the most impressive features of the proposed model of governance is the lack of any reference to the role of international organisations (and, less surprisingly, non-state actors) not only in the chapter on multilateral cooperation, but in both documents generally. This is indicated by the commit-

18 See for instance, Parag Khanna, The Future is Asian (New York: Simon \& Schuster 2019), 281-325, in particular 286 et seq., 300 et seq.

19 Yan Xuetong, Leadership and the Rise of Great Powers (Princeton: Princeton University Press 2019). 
ment of both States in the Joint Statement to "jointly uphold the authority of multilateral platforms', ${ }^{20}$ whereby they avoid using the possible phrase of 'international organisations and other multilateral platforms'. The two powers may so express their deep mistrust to the system of international organisations as a creation of the Western-dominated global order and their preference for ad hoc 'conferences', under the control of the Concert of Global Powers. This is a very state-centric philosophy of global governance.

\section{Prospects}

The 2021 Joint Statement and the 2016 Declaration design an alternative future for the 21st century. The global governance they propose intends to create a world order of spheres of influence, under the control of a two-tier Concert of Global Powers, acting beyond the framework of the United Nations and of other international organisations. The proposed system has some pros, but many more cons.

The envisaged informal Concert seems to be separate from the UN system, or very loosely linked to it, and has the purpose of enabling a direct dialogue among the P5 in consultation and with input from the other major global powers. Considering that the UN Security Council is composed of the P5 plus states representing of the various world regions, ${ }^{21}$ the changes proposed by the Joint Statement constitute a movement towards a more oligarchic system, where the second tier is composed of major global powers, as well. This proposal could be appealing, if at all, for some middle powers that had hoped for a reform of the Security Council and a possible long-term or permanent membership.

The logic of such a system should not be dismissed out of hand. Its justification is that major problems and crises can be resolved only if global powers act in unison and push the parties into an arrangement, even with some arm-twisting. Its rationale is that unending negotiations 'on equal footing' are counterproductive and they unnecessarily prolong conflicts instead of resolving them.

The problem with such a proposal is that a common approach of the powerful States has worked in the immediate post-Cold War period, but not anymore. The question is, why the three remaining members of the P5 would be willing to act within the Concert, but not under the rules of the Council. One explanation might be that, by suggesting this system, Russia and China

20 Para. 4, emphasis added by the author.

21 Art. 23 (1) UN Charter ('equitable geographical distribution’). 
are trapped in wishful thinking. This cannot be excluded, but they still are aware that they have to share authority with other powers. Another explanation might suggest that the Statement is a demonstrative expression of their 'will to power' and their ambition to reshape the current world order.

We may speculate on three possible futures. The first is the 'no major change' future, where the current state of affairs, relying on a balance of power with relative primacy of the West, could continue with some fluctuations throughout the 21 st century. In this scenario the project for an authoritarian global governance would become obsolete, sooner or later.

The second is a future where the system proposed by the Joint Statement could be implemented, if the balance of power would irreversibly shift in favour of the two authoritarian powers. If the weakness of the West reaches a point of no return, Russia and China could set the agenda and nudge the other global powers to join the Concert, acquiescing to their leading role. Such a development is improbable, but not impossible, taking into account that since the $2000 \mathrm{~s}$, a series of systemic crises have shocked the West, whilst China's reach around the world, including via the Belt and Road Initiative, has increased. Depending on the circumstances, parts of the global public might be more receptive to the promise of authoritarian and technocratic global governance. In an era of global risks and global angst, authoritarian systems have an argument, but this may not be sufficient to win predominance in world affairs.

In a third future, Russia and China may miscalculate, by overestimating their own strength and by underestimating the intensity of conflicts of interest within the authoritarian geopolitical space, the resilience and reform capacity of democratic societies and the dynamic of world society. The two powers may not be able to bring their own systemic crises under control and may face a reformed West that has overcome its internal divisions, due to the flexibility of its society and its capitalism. Moreover, new emerging regional geopolitical and geo-economic spaces, systems, and centres, in particular in developing countries, may create technological and economic hubs demonstrating the potential of the periphery and undermining the projects of domination by global powers.

Here lies the significance of the Joint Statement of March 2021. This is neither a revolutionary program written in stone, nor an ephemeral political declaration. It is rather a step in a centennial struggle on how the world should be ruled.

Achilles Skordas 